DOI: $10.21802 / \operatorname{artm} .2019 .3 .11 .73$.

УДК 616.72-002.78-06:616-008.9]-085.272.4/.322

\title{
ЕФЕКТИВНІСТЬ БІОФЛАВОНОЇДІВ ПРИ ЛІКУВАННІ ХВОРИХ НА ПОДАГРУ НА ТЛІ МЕТАБОЛІЧНОГО СИНДРОМУ
}

\author{
О.О. Якименко, М.В. Гриценко
}

Одеський національний медичний університет, кафедра пропедевтики внутрішніх хвороб та терапії, м. Одеса, Україна, ORCID ID: 0000-0002-6062-8890, ORCID ID: 0000-0002-0545-3274, e-mail: hrytsenko.mv@gmail.com

Резюме. Метою дослідження було оцінити ефективність застосування біофлавоноїду кверцетину у хворих на подагру на тлі метаболічного синдрому.

Об'єкт і методи дослідження. Обстежено 61 пацієнта 3 первинною подагрою в поєднанні з метаболічним синдромом та виділені групи пацієнтів. Основній групі $(\mathrm{n}=30)$ було призначено алопуринол (початкова доза 100 мг на добу з наступним титруванням дози до підтримуючої) та квертин 40мг по 1 таблетці 3 рази на добу протягом 6 місяців, з повторенням курсу через 2-3 місяці. Групі порівняння (n=31) тільки алопуринол. Схема лікування була призначена у період ремісії. Оцінку ефективності проводили через 12 та 24 місяці за допомогою лабораторних методів дослідження.

Результати. При динамічному спостереженні на фоні лікування відмічалася тенденція до зниження концентрації сечової кислоти через 12 місяців на 38,35 \% в першій групі та на $23 \%$ в другій групі, а через 24 місяці на 49,12 \% в першій групі та на 36,68 \% в другій групі. Через 12 та 24 місяці відмічалося статистично достовірне зниження С-реактивного протеїну та сіромукоїдів в основній групі, в той же час фібриноген та швидкість осідання еритроцитів мали тенденцію до зниження, але різниця була статистично недостовірною. При оцінці функції нирок відмічалося достовірне зниження концентрації креатиніну та сечовини та збільшення швидкості клубочкової фільтрації в основній групі. Також у групі 1 достовірно знизився рівень холестерину ліпопротеїнів низької щільності через 12 місяців та 24 місяці та підвищився рівень холестерину ліпопротеїнів високої щільності; щодо рівня загального холестерину та тригліцеридів, то відмічалася тенденція до зниження цих показників. В той же час у групі 2 суттєвих відмінностей не було.

Ключові слова: подагра, метаболічний синдром, біофлавоноїди, кверцетин.

Вступ. Характеризуючи захворюваність на подагру на сучасному етапі, слід зазначити ii зростання в останні десятиріччя як в Україні, так і у світі, збільшення захворюваності серед жінок, а також зростаючий рівень коморбідності, значне місце серед якої посідає метаболічний синдром $[1,2]$.

Подагра $є$ частою причиною як тимчасової, так і стійкої втрати працездатності і в перший рік діагностується лише у 10-15 \% пацієнтів [3]. Прогресування подагри характеризується ураженням внутрішніх органів: нирок, печінки, серця, судин, що значно погіршує якість життя пацієнтів та прогноз захворювання.

Серед коморбідної патології у хворих на подагру значне місце посідають метаболічні розлади порушення вуглеводного та ліпідного обміну, артеріальна гіпертензія, що об'єднуються у понятті метаболічний синдром (МС). Ряд популяційних досліджень у США, Південній Кореї, Мексиці показали, що МС виявляється у 57-85 \% хворих на подагру, що в три рази частіше, ніж у пацієнтів без подагри [4-7].

Терапія подагри в основному сконцентрована на корекції дієти, пригніченні гострого запального процесу та нормалізації концентрації сечової кислоти 3 метою зменшення проявів артриту, в той час як профілактиці системних уражень внутрішніх органів, особливо з субклінічними проявами, приділяється недостатньо уваги [3].

Найбільш тяжким вісцеральним ускладненням подагри, яке загрожує життю пацієнта, є ураження нирок - подагрична нефропатія. Механізм ураження нирок при подагрі полягає не тільки у механічному ураженні кристалами моноурату натрію, а й розвитком системного запалення та ендотеліальної дисфункції [8].

3 огляду на ці механізми патогенетично обгрунтованим $є$ застосування рослинних біофлавоноїдів 3 антиоксидантною дією, серед яких можна виділити кверцетин.

Кверцетин інгібує активні форми кисню, вільні радикали, синтез лейкотрієнів, блокує проведення та реалізацію сигналу в кальцій-мобілізуючій поліфосфоінозитидній системі та активує аденілатциклазний каскад [9]. Окрім вираженої антиоксидантної дії, квериетин проявляє мембранстабілізуючий, протизапальний та гіпоурикемічний ефект [10-12].

Мета: оцінити ефективність застосування біофлавоноїду кверцетину у хворих на подагру на тлі метаболічного синдрому.

Об'єкт і методи дослідження: Обстежено 61 пацієнта 3 первинною подагрою в поєднанні з МС. Всі пацієнти чоловіки віком від 38 до 72 (середній вік 
- 53,4 $\pm 5,9)$, які зверталися на амбулаторний прийом до ревматологічного відділення БМЦ ОНМедУ протягом 2016-2018 років. Діагноз подагри виставлений на підставі класифікаційних критеріїв EULAR/ACR (2015), MC діагностувався згідно 3 рекомендаціями Української асоціації кардіологів (2004). Середня тривалість подагри склала $7 \pm 1,9$ років. Критерії включення у дослідження: первинна подагра, рентгенологічна стадія 2-3, ступінь функціональної недостатності I-II, наявність МС. Критерії виключення: вторинна подагра, ендокринна патологія, хронічна хвороба нирок 3-5 стадії.

Всі пацієнти шляхом рандомізації були розподілені на дві групи: перша - основна $(\mathrm{n}=30)$ та друга - група порівняння $(\mathrm{n}=31)$, критерісм розподілу було включення препарату «Квертин» виробництва ЗАТ НВЦ «Борщагівський ХФЗ» (діюча речовина біофлавонїд кверцетин) до комплексного лікування. Основній групі було призначено алопуринол (початкова доза 100 мг на добу з наступним титруванням дози до підтримуючої дози 300 мг/добу для досягнення цільового рівня сечової кислоти (СК) менше 360 ммоль/л) та квертин 40мг по 1 табл. 3 рази на добу протягом 6 місяців, з повторенням курсу через 2-3 місяці. Групі порівняння тільки алопуринол (початкова доза 100 мг на добу з наступним титруванням дози). Схема лікування була призначена у період ремісії.

Пацієнти були обстежені на початку лікування та через 12 та 24 місяці. Всім було проведено збір анамнезу, фізикальне обстеження, вимірювання артеріального тиску, об’єму талії, ваги, визначення індексу маси тіла, дослідження лабораторних показників, а саме загальний аналіз крові та сечі, біохімічні аналізи крові (визначення концентрації СК, креатиніну, глюкози плазми крові натще, загального холестерину, тригліцеридів, холестерину ліпопротеїнів високої та низької щільності (ЛПВЩ і ЛПНЩ), Среактивного пептиду (СРП), фібриногену, сіромукоїдів, швидкості осідання еритроцитів (ШОЕ), розрахунок швидкості клубочкової фільтрації (ШКФ)). Інструментальні методи дослідження включали рентгенографію суглобів, ультразвукове дослідження нирок.

Статистична обробка даних виконана за допомогою програми Excel. Вираховували середню величину та іiі стандартну похибку (середнього) $(\mathrm{M} \pm \mathrm{m})$. Оцінку достовірності проводили за допомогою критерію Манна - Уїтні та критерій Фішера за показником Р. Різниця вважалася достовірною при $\mathrm{p}<0,05$.

Результати дослідження та їх обговорення. Сформовані досліджувані групи достовірно не відрізнялися за значущими клініко-анамнестичними даними (вік, тривалість подагри, ступінь функціональної недостатності) та лабораторними даними (концентрація СК, креатиніну, ШКФ, ліпідограма).

При динамічному спостереженні обох груп пацієнтів на фоні лікування відмічалася тенденція до зниження концентрації СК через 12 місяців на $38,35 \%$ у першій групі та на $23 \%$ у другій групі, а через 24 місяці на 49,12\% у першій групі та на 36,68 \% у другій групі (p>0,2) (рис.1).

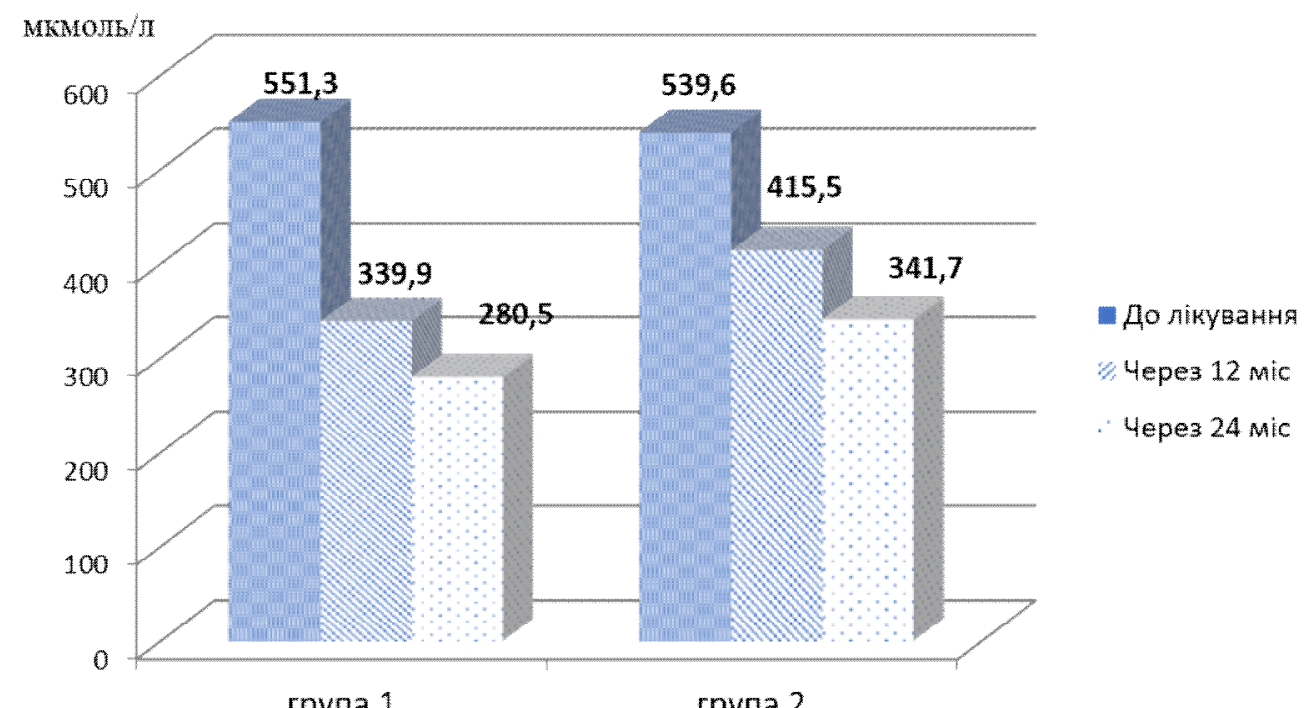

Рис. 1. Динаміка зниження концентрації сечової кислоти на фоні лікування у досліджуваних груп

Застосування квертину поряд зі стандартною схемою лікування сприяло покращенню біохімічних маркерів запалення. Через 12 та 24 місяці відмічалося статистично достовірне зниження таких гострофазових показників в основній групі як СРП та сіромукоїди, у той же час фібриноген та ШОЕ мали тенденцію до зниження, але різниця була статистично недостовірною (табл. 1).
Наступним етапом дослідження була оцінка функції нирок. Для цього були використані стандартні дослідження, а саме визначення концентрації креатиніну, сечовини та розрахунок ШКФ. Статистично значуще покращення спостерігалось в основній групі (табл. 2). 
Таблиця 1

Динаміка гострофазових показників запалення у пацієнтів у різних групах проведеної терапії

\begin{tabular}{|c|c|c|c|c|c|c|}
\hline \multirow{2}{*}{ Показники $^{1}$} & \multicolumn{3}{|c|}{ Група 1 (n=30) } & \multicolumn{3}{c|}{ Група 2 (n=31) } \\
\cline { 2 - 7 } & До лікування & Через 12 міс. & Через 24 міс. & До лікування & Через 12 міс. & Через 24 міс. \\
\hline СРП (мг/л) & $9,7 \pm 0,41$ & $5,2 \pm 0,35^{*}$ & $4,6 \pm 0,16^{* *}$ & $9,5 \pm 0,52$ & $6,2 \pm 0,23^{*}$ & $5,6 \pm 0.47^{* *}$ \\
\hline $\begin{array}{c}\text { Фібриноген } \\
\text { (г/л) }\end{array}$ & $5,4 \pm 0,58$ & $3,8 \pm 0,29$ & $3,7 \pm 0.47$ & $4,8 \pm 0,61$ & $4,2 \pm 0,32$ & $4,0 \pm 0.26$ \\
\hline $\begin{array}{c}\text { Сіромукӧди } \\
\text { (од.) }\end{array}$ & $0,326 \pm 0,002$ & $0,256 \pm 0,009^{*}$ & $0.241 \pm 0.007^{* *}$ & $0,320 \pm 0,002$ & $0,280 \pm$ & $0,292 \pm$ \\
\hline ШОЕ (мм/год) & $24 \pm 2,12$ & $14 \pm 0,41$ & $11 \pm 0,53$ & $19 \pm 1,06$ & $15 \pm 0,96$ & $12 \pm 0,72$ \\
\hline
\end{tabular}

Примітка: ${ }^{1}$ дані представлені у вигляді: середнє \pm стандартне відхилення;

* p<0,05 при порівнянні через 12 міс. відповідних показників у групах;

** p<0,05 при порівнянні через 24 міс. відповідних показників у групах.

Таблиця 2

Динаміка основних показників ниркової функції у досліджуваних групах хворих

\begin{tabular}{|l|c|c|c|c|c|c|}
\hline \multirow{2}{*}{ Показники } & \multicolumn{3}{|c|}{ Група 1 $(\mathrm{n}=30)$} & \multicolumn{3}{|c|}{ Група 2 (n=31) } \\
\cline { 2 - 7 } & До лікування & Через 12 міс. & Через 24 міс. & До лікування & Через 12 міс. & Через 24 міс. \\
\hline $\begin{array}{l}\text { Креатинін, } \\
\text { ммоль/л }\end{array}$ & $113,14 \pm 1,23$ & $84 \pm 1,36^{*}$ & $74 \pm 1.45^{* *}$ & $111,45 \pm 0,41$ & $93 \pm 1,87^{*}$ & $84 \pm 1,9^{* *}$ \\
\hline $\begin{array}{l}\text { Сечовина, } \\
\text { ммоль/л }\end{array}$ & $10,01 \pm 0,732$ & $9,2 \pm 0.34^{*}$ & $6,8 \pm 0.16^{* *}$ & $11,2 \pm 0,84$ & $10,4 \pm 0,35^{*}$ & $7,8 \pm 0,47^{* *}$ \\
\hline $\begin{array}{l}\text { ШКФ, мл/хв } \\
/ 1,73 \mathbf{m}^{2}\end{array}$ & $62,4 \pm 1,6$ & $93,1 \pm 1,2^{*}$ & $97,3 \pm 1,14^{* *}$ & $62,9 \pm 1,2$ & $78,2 \pm 1,1^{*}$ & $88,5 \pm 1,2^{* *}$ \\
\hline
\end{tabular}

Примітка: ${ }^{1}$ дані представлені у вигляді: середнє \pm стандартне відхилення;

* p<0,05 при порівнянні через 12 міс. відповідних показників у групах;

** $\mathrm{p}<0,05$ при порівнянні через 24 міс. відповідних показників у групах.

Також були проаналізовані дані ліпідограми. Як видно 3 таблиці 3, у групі 1 достовірно знизився рівень ХС ЛПНЩ через 12 місяців та 24 місяці, а також підвищився рівень ХС ЛПВЩ щодо рівня зага- льного ХС та ТГ, відмічалася тенденція до зниження цих показників. У той час у групі 2 суттєвих відмінностей не було.

Динаміка показників ліпідограми в досліджуваних групах хворих

\begin{tabular}{|c|c|c|c|c|c|c|}
\hline \multirow{2}{*}{\begin{tabular}{c} 
Показники \\
\cline { 2 - 7 }
\end{tabular}} & \multicolumn{3}{|c|}{ Група 1 $(\mathrm{n}=30)$} & \multicolumn{3}{c|}{ Група 2 (n=31) } \\
\hline $\begin{array}{c}\text { Загальний ХС } \\
\text { ммоль/л }\end{array}$ & $6,02 \pm 1,1$ & $5,43 \pm 1,06$ & $5,02 \pm 0,94$ & $6,15 \pm 1,15$ & $6,02 \pm 0,94$ & $6,4 \pm 0,78$ \\
\hline ТГ, ммоль/л & $2,15 \pm 0,32$ & $1,97 \pm 0,56$ & $1,8 \pm 0,69$ & $2,34 \pm 0,65$ & $2,57 \pm 0,43$ & $2,12 \pm 0,59$ \\
\hline $\begin{array}{c}\text { ХС ЛПВЩ, } \\
\text { ммоль/л }\end{array}$ & $1,34 \pm 0,11$ & $1,67 \pm 0,12^{*}$ & $1,73 \pm 0,16^{*}$ & $1,52 \pm 0,38$ & $1,34 \pm 0,21$ & $1,72 \pm 0,37$ \\
\hline $\begin{array}{c}\text { ХС ЛПНЩ, } \\
\text { ммоль/л }\end{array}$ & $3,96 \pm 0,13$ & $3,56 \pm 0,15^{*}$ & $3,51 \pm 0,12^{*}$ & $4,08 \pm 0,14$ & $4,19 \pm 0,16$ & $4,23 \pm 0,19$ \\
\hline
\end{tabular}

Примітка: ${ }^{1}$ дані представлені у вигляді: середнє \pm стандартне відхилення; ХС - загальний холестерин; ТГ тригліцериди; ЛПВЩ - ліпопротеїни високої щільності; ЛПНЩ - ліпопротеїни низької щільності; * р<0,05 при порівнянні через 12 міс. відповідних показників у групі;** $\mathrm{p}<0,05$ при порівнянні через 24 міс. відповідних показників у групі.

Механізм дії кверцетину полягає у інгібіції синтезу лейкотріснів, блокаді проведення та реалізації сигналу в кальцій-мобілізуючій поліфосфоінози- тидній системі, активації аденілатциклазного каскаду, інгібіції ксантиноксидази, завдяки чому і досягається протизапальна, антиоксидантна та гіпоурикемічна 
дія. Ці ефекти допомагають зменшенню прогресування подагричного артриту та запобігають ускладнень 3 боку внутрішніх органів у пацієнтів 3 подагрою та MC. Враховуючи те, що надлишок сечової кислоти сприяє розвитку атеросклерозу та хронічній хворобі нирок, порушує клубочкову фільтрацію, пошкоджуює інтерстицій, нормалізація цього показника є важливої складовою лікування хворих на цю патологію. Також кверцетин сприяє нормалізації ліпідного обміну, а отже додавання його в схему комплексного лікування пацієнтів з подагрою та МС є патогенетично обгрунтованим.

Висновки. Застосування кверцетину при лікуванні хворих на подагру з МС є ефективним доповненням до стандартної схеми лікування, що більш значуще зменшує рівень СК в крові, покращує функцію нирок та нормалізує показники ліпідного обміну, сприяє зниженню вираженості запального процесу за даними біохімічних досліджень.

\section{References:}

1. Svintsytsky AS, Kozak NP, Ostafiychuk AS. Osoblyvosti perebihu podahry na foni metabolichnoho syndromu. Ukr. revmatol. zhurnal. 2011; 4. P.46. [in Ukrainian]

2. Roddy E, Choi HK. Epidemiology of gout. Rheumatic Disease Clinics. 2014; 40(2):155-175.

3. Voloshin OI, Pishak OV, Arich GI, Voloshina LO. Fitoterapiya podahry (Ohlyad literatury ta rezul'taty vlasnykh doslidzhen'. Fitoterapya. Chasopys. 2011; 2:1521. [in Ukrainian]

4. Richette P, Clerson P, Périssin L, Flipo RM, Bardin T. Revisiting comorbidities in gout: a cluster analysis. Annals of the rheumatic diseases. 2015; 74(1):142-147.

5. González-Senac NM, Bailén R, Torres RJ, de Miguel E, Puig JG. Metabolic syndrome in primary gout. Nucleosides, Nucleotides and Nucleic Acids. 2014; 33(46):185-191.

6. Kim Y, Kang J, Kim GT. Prevalence of hyperuricemia and its associated factors in the general Korean population: an analysis of a population-based nationally representative sample. Clinical rheumatology. 2018; 37(9):2529-2538.

7. Wei CY, Sun CC, Wei JC, Tai HC, Sun CA, Chung $\mathrm{CF}$, et al. Association between hyperuricemia and metabolic syndrome: an epidemiological study of a labor force population in Taiwan. BioMed research international, 2015.

8. Puddu P, Puddu GM, Cravero E, Vizioli L, Muscari A. The relationships among hyperuricemia, endothelial dysfunction, and cardiovascular diseases: molecular mechanisms and clinical implications. Journal of cardiology. 2012; 59(3):235-242.

9. Zupanets IA, Usenko VF, Shalamay AS. Doslidzhennya vplyvu novoho vuhlevodmodyfikovanoho preparatu kvertsytynu na perebih kolahen-indukovanoho artrytu u shchuriv. Ukr. revmatol. zhurnal. 2011; (4):1517. [in Ukrainian]

10. Zhang C, Wang R, Zhang G, Gong D. Mechanistic insights into the inhibition of quercetin on xanthine oxidase. International journal of biological macromolecules. 2018; 112:405-412.
11. Ruiz-Miyazawa KW, Staurengo-Ferrari L, Mizokami SS, Domiciano TP, Vicentini FT, Camilios-Neto D et al. Quercetin inhibits gout arthritis in mice: induction of an opioid-dependent regulation of inflammasome. Inflammopharmacology. 2017; 25(5):555-570.

12. Cao H, Pauff JM, Hille R. X-ray crystal structure of a xanthine oxidase complex with the flavonoid inhibitor quercetin. Journal of natural products. 2014; 77(7):16931699.

УДК 616.72-002.78-06:616-008.9]-085.272.4/.322

\section{ЭФФЕКТИВНОСТЬ БИОФЛАВОНОИДОВ ПРИ ЛЕЧЕНИИ БОЛЬНЫХ ПОДАГРОЙ НА ФОНЕ МЕТАБОЛИЧЕСКОГО СИНДРОМА}

\section{Е.А. Якименко, М.В. Гриценко}

Одесский национальный медицинский университет, кафедра пропедевтики внутренних болезней и

терапии, г.Одесса, Украина,

ORCID ID: 0000-0002-6062-8890,

ORCID ID: 0000-0002-0545-3274,

e-mail: hrytsenko.mv@gmail.com

Резюме. Целью исследования было оценить эффективность применения биофлавоноида кверцетина у больных подагрой на фоне метаболического синдрома.

Объект и методы исследования. Обследован 61 пациент с первичной подагрой в сочетании с метаболическим синдромом и выделено две группы. Основной группе $(n=30)$ был назначен аллопуринол (начальная доза 100 мг в сутки с последующим титрованием до поддерживающей) и квертин 40 мг по 1 табл. 3 раза в сутки в течение 6 месяцев, с повторением курса через 2-3 месяца. Группе сравнения $(\mathrm{n}=31)$ только аллопуринол. Схема лечения была назначена в период ремиссии. Оценку эффективности проводили через 12 и 24 месяца с помощью лабораторных методов исследования.

Результаты. При динамическом наблюдении на фоне лечения отмечалась тенденция к снижению концентрации мочевой кислоты через 12 месяцев на $38,35 \%$ в первой группе и на $23 \%$ во второй группе, а через 24 месяца на 49,12\% в первой группе и на $36,68 \%$ во второй группе. Через 12 и 24 месяца отмечалось статистически достоверное снижение Среактивного протеина и серомукоидов, в то же время фибриноген и скорость оседания эритроцитов имели тенденцию к снижению, но разница была статистически недостоверной. При оценке функции почек отмечалось достоверное снижение концентрации креатинина и мочевины и увеличение скорости клубочковой фильтрации в основной группе. Также в группе 1 достоверно снизился уровень холестерина липопротеинов низкой плотности через 12 месяцев и 24 месяца и повысился уровень холестерина липопротеинов высокой плотности, относительно уровня общего холестерина и триглицеридов отмечалась тенденция к снижению этих показателей. В то же время в группе 2 существенных различий не было. 
Ключевые слова: подагра, метаболический синдром, биофлавоноиды, кверцетин.

\section{UDC 616.72-002.78-06:616-008.9]-085.272.4/.322 EFFICIENCY OF BIOFLAVONOIDS IN THE TREATMENT OF PATIENTS WITH GOUT ON THE BACKGROUND OF METABOLIC SYNDROME}

O.O. Yakimenko, M.V. Hrytsenko

Odessa National Medical University, Department of Propaedeutics of Internal Medicine and Therapy,

Odessa, Ukraine,

ORCID ID: 0000-0002-6062-8890,

ORCID ID: 0000-0002-0545-3274,

e-mail:hrytsenko.mv@gmail.com

Abstract. The aim of the study was to evaluate the effectiveness of the use of bioflavonoid quercetin in patients with gout on the background of metabolic syndrome.

Object and research methods. Sixty-one patients with primary gout in combination with metabolic syndrome were examined. All patients were male with an average age of $53.4 \pm 5.9$ years. The average duration of gout was $7 \pm 1.9$ years. Criteria for inclusion in the study: primary gout, $x$-ray stage $2-3$, the degree of functional insufficiency I-II, the presence of metabolic syndrome. Exclusion criteria: secondary gout, endocrine pathology, chronic kidney disease 3-5 stage.

All patients were divided into two groups - the first - the main $(\mathrm{n}=30)$ and the second - the comparison group $(\mathrm{n}=31)$. In the main group allopurinol was administered (initial dose of $100 \mathrm{mg}$ per day, followed by titration of the dose to a maintenance dose of $300 \mathrm{mg}$ per day to achieve the target uric acid level of less than $360 \mathrm{mmol}$ / 1) and quertin $40 \mathrm{mg}, 1$ tablet 3 times a day for 6 months, with a repetition of the course after 2-3 months. In comparison group, only allopurinol was administered (initial dose of $100 \mathrm{mg}$ per day, followed by dose titration). The treatment regimen was prescribed during the period of remission. Efficiency assessment was carried out after 12 and 24 months.
All patients were subjected to anamnesis, physical examination, blood pressure measurement, waist volume, weight, determination of body mass index, study of laboratory parameters, namely general blood and urine analysis, biochemical blood tests (determination of concentration of uric acid, creatinine, fasting plasma glucose, total cholesterol, triglycerides, high and low density lipoprotein cholesterol, C-reactive peptide, fibrinogen, seromucoids, erythrocyte sedimentation rate, glomerular filtration rate calculation). Instrumental methods of examination included radiography of the joints, ultrasound examination of the kidneys.

Results. At dynamic observation during treatment, there was a tendency to a decrease in uric acid concentration after 12 months by $38.35 \%$ in the first group and by $23 \%$ in the second group and after 24 months by $49.12 \%$ in the first group and by $36.68 \%$ in second group. However, the difference between the indicators in both groups was statistically significant $(\mathrm{P}>0,2)$. After 12 and 24 months, a statistically significant decrease in such inflammatory markers in the main group as $\mathrm{C}$-reactive peptide and seromucoids was noted, at the same time fibrinogen and erythrocyte sedimentation rate tended to decrease, but the difference was not statistically significant. In assessing renal function, a significant decrease was observed in the concentration of creatinine and urea and an increase in glomerular filtration rate in the main group were noted. Lipidogram data were also analyzed - in group 1, the level of low-density lipoprotein cholesterol significantly decreased after 12 months and 24 months, and the level of high-density lipoprotein cholesterol increased, relative to the level of total cholesterol and triglycerides there was a downward trend in these indicators. At the same time, there were no significant differences in group 2.

Conclusions. The use of quercetin in the treatment of patients with gout on the background of metabolic syndrome is an effective addition to the standard treatment regimen, which significantly reduces the level of uric acid in the blood, improves kidney function and normalizes the lipid metabolism, helps to reduce the severity of the inflammatory process.

Keywords: gout, metabolic syndrome, bioflavonoids, quercetin. 